\title{
Islamic English in Islamic Talks
}

\author{
$K$. Othman ${ }^{1, *}$ and $A . I$. Ismail ${ }^{2}$ \\ ${ }^{1}$ Centre for Languages and Pre-University Academic Development \\ ${ }^{2}$ Department of English Language and Literature, International Islamic University Malaysia
}

\begin{abstract}
The international nature of the English language has affected many communities across the globe and this has led to the emergence of varieties of English, specifically to meet the needs of non-native speakers of English. For Muslim speakers, Islamic English has been proposed which aims to maintain Arabic terms in the English language when there is an absence of equivalent English words. An attempt to translate would lead to distortion in meanings. This paper aims to highlight the presence of Islamic English employed by a prominent international Islamic speaker. Content analysis method is employed. The findings indicate the functions of Islamic English in the speaker's talks are to provide the accurate meaning of the terms, correct misconceptions and lack of equivalent word in the English language, hence the need for Islamic English for Muslim speakers of English.
\end{abstract}

\section{Introduction}

Recent decades have witnessed the spread of the English language across the globe which has become the lingua franca of the $21^{\text {st }}$ century. It has empowered and brought mobility to its users, especially non-native speakers of the English language. In fact, as puts it [1], the English language has become localised in its journey to become an international language. He further elaborates that people from different cultures have adopted the language to express themselves based on their cultures which leads to 'nativisation' of language and development of new varieties of English. Examples of these varieties of English include Pakistani English, Saudi English, Korean English, Singaporean English and Indian English [2-6]. For Muslims, they do not only use the language in communication, education, politics and business but also as a means to convey the message of Islam to the global audience, especially to non-Muslim English speaking audience. The tendency for Muslim speakers to maintain some Arabic terms due to the absence of equivalent meaning in the English language has led to the usage of Islamic English, a new variety of English. This paper aims to highlight the presence of Islamic English used by a prominent international Islamic speaker and its functions, hence the importance of maintaining Arabic Islamic terms in discourse particularly among Muslims.

\section{Islamic English}

The significant rise in the number of English-speaking Muslims around the world has called for more attention on the proper usage of Islamic or divine terms in the English language. The preservation of religious and spiritual values of Arabic words in the English language is essential to avoid change, loss of meaning and obliteration through translation or transliteration process.
According to al-Faruqi who advocates Islamic English, the term refers to "the modified English language to enable it to carry Islamic proper nouns and meanings without distortion" which involves "the infusion of religious, spiritual and cultural terms of Islam to modern English" [7]. The aim is to "serve the needs of the Muslim users of the English language" in an attempt to protect English speaking Muslims from being influenced by the negative values and culture of the west. Abdul Salam concurs that any language that Muslims use, not just English needs to be "Islamised with features that enable it to convey Islamic belief, values, and heritage" [8]. Since majority of Pakistanis and Saudis are Muslims, it is found that Pakistani English and Saudi English reflect Islamic values and beliefs [2,3].

Al-Faruqi discusses the nature of current distortion in transliteration of Prophet Muhammad's name [7]. The spelling of Prophet Muhammad's name for instance, has been changed into Maumet, Mawmet and Mahound. Webster International Dictionary (www.webster-dictionary.org) for instance, misspells Prophet Muhammad's name as Mawmet and defines it as "a false god or idol arising from a belief that Mohammedans worshiped images of Mohammed." [7]. This inaccurate and false definition of Prophet Muhammad could lead to confusion not only to nonMuslim English speakers but also to young Muslims. Therefore, the meanings of Arabic names and words must be translated properly to preserve its divine meanings.

The needed rectification in translation has also been discussed by Al-Faruqi [7]. The titles of verses in AlQuran, Allah's and Prophets' divine names and terms in Islamic laws and concepts are the general rules listed by Al-Faruqi as a guideline for translation in Islamic English. For example, surah Al-Ikhlas, Al-Azim, Muhammad and halal [7]. While the spelling of these Arabic words must be preserved, the meanings are equally important. For instance, halal in Islam means

*Corresponding author: khairiah@iium.edu.my 
"that which Allah s.w.t. has made legitimate" [7]. AlFaruqi emphasizes that Arabic words must not be easily translated and defined into English. $\mathrm{He}$ is concerned that when translated, users might change the meaning of the Arabic divine words and further cause misconceptions in Islam.

\section{Method}

The talks of a prominent contemporary international Islamic speaker, Dr Zakir Naik are chosen due to his achievements and recognition in the field of propagation of Islam and inter-religious speeches. Three speeches are selected to ensure consistency in the findings. There are as follows:

Speech 1: "Islam and the 21st Century" was delivered on 11 February 2011 at the Oxford Union Historic Debate in Oxford University, England. https://www.youtube.com/watch? $\mathrm{v}=\mathrm{rdoCzv} 28 \mathrm{IOw}$.

The audience were educated non-Muslims [9].

Speech 2: "The Solution for Humanity 2015" was delivered on 13 January 2015 at the Dubai Conference Centre, United Arab Emirates. https://www.youtube.com/watch?v=mzPtHsb3fiw. The audience were Muslims [10]

Speech 3: "Islam's View on Terrorism and Jihad" was delivered on 7 October 2015 at the Putra World Trade Centre, Kuala Lumpur, Malaysia. https://www.youtube.com/watch?v=c7Hr8bW5PyU. The audience consisted of Muslims and non-Muslims [11]

The speeches were first transcribed before the Islamic English terms were identified and analysed.

\section{Finding and Discussion}

The findings indicate the presence of Islamic English in all the three speeches by Zakir Naik. The main function as to why the Arabic terms are used is to correct misconceptions and to give the accurate meanings. In speech one, for instance, when Zakir Naik talked about "Islam and the 21 st century", he stated that the most misunderstood word in Islam is the word jihad. He said in the 21 st century, jihad is often mistranslated as holy war that aims for personal gain, fame, honour or land. The truth of what he is saying could be seen for example, in the definition of jihad which is given by the official Collins English Dictionary online which defines jihad as a "a holy war which Islam allows Muslims to fight against those who rejects its teachings", besides "a holy war against infidels undertaken by Muslims in defence of the Islamic faith" and "the personal struggle of the individual believer against evil and persecution" [12]. The third edition of Cambridge Advanced Learner's Dictionary has similarly defined jihad as "a holy war which is fought by Muslims against people who are a threat to the Islamic religion or who oppose its teachings" [13]. Zakir Naik corrected this information by stating that the word holy war was first used during the Crusades war where the Crusaders forced people to accept the religion of Christianity. In Islam, religion should not be forced, but embraced by one own's free will. Unfortunately, asserted Zakir, the word holy war is used to describe the propagation of Islam by force and war. From the Islamic context, jihad means to strive and struggle in order to improve the society, for self-defence, against injustice operation, or one's own selfish intention. He even gave an example of a student who struggles to pass an examination is in fact doing his jihad. The extract of his speech is as follows:

"And the most misunderstood word regarding Islam is the word jihad. It is not only misunderstood by the Muslims, but it is also misunderstood by the Muslims. Most of the people whether they are Muslims or nonMuslims, they think that any war, by any reasons, whether it is for personal gain, whether it be for fame, honour or land, any war by any Muslim is called jihad. Jihad is derived from the Arabic word jahada, which means to strive, to struggle. In the Islamic context, jihad means to strive or to struggle against one own intention. Jihad also means to struggle, to strive to make the society better. Jihad also means to strive and struggle for self-defence. So jihad basically means to strive and struggle. For example, a student is struggling to pass a certain examination, and we will say that he is doing jihad. So jihad basically means to strive and struggle".

Similarly, in his speech entitled "Islam's View on Terrorism and Jihad", he reiterated the word jihad as misunderstood not only by non-Muslims, but also by Muslims. He again elaborated on the accurate meanings of jihad as follows;

"The most misunderstood word in Islam is jihad. It is not just been misunderstood by the non-Muslims, but also misunderstood by the Muslims. Jihad is derived from the Arabic word, jahada, which means to strive or to struggle. In Islam, jihad means to struggle against one's own desire. Jihad means to strive and struggle to make the society better. Jihad means to strive and struggle against operation. Jihad also means to strive and struggle in the battle field for self-defence. Jihad basically means to strive and struggle. Jihad is always misunderstood as the war by Muslims against the nonMuslims, for any reason, whether it be for personal gain, whether it be for fame, for wealth, for religion, for fame for power, it's called as jihad."

Zakir Naik also expressed his disappointment when the Muslims themselves translated the word jihad incorrectly.

"Most of the orientalists, they translate jihad as holy war. Unfortunately, Muslims scholars inverted comas, even they translate jihad as a holy war. Holy war if you translate in Arabic word is harbun muqddasa. If you read the Quran, never it is mentioned the word alharbun muqaddasa in the Quran. There is no hadith where the word harbun muqaddasa is mentioned. The word holy war was first coined by the Crusades and by the Christian. If you read history, the Christian crusaders, they forced and killed thousands of human beings in the name of Christianity... Today it is 
used in the English language to define jihad. In short, jihad does not mean holy war".

In this speech, he addressed that even the Muslim scholars had carelessly translated the word jihad as holy war. Zakir Naik referred to the history of the word holy war which the term was first used by the Christian Crusaders, not by the Muslims. Muslims do not use the term holy war or translated in Arabic as harbun muqddasa to mean jihad. Zakir Naik explained the divine term jihad in his speeches. It shows his urgency to correct misunderstanding by providing the correct translation of the word jihad as to strive and struggle.

Zakir Naik also took the opportunity to explain the concept of hijab which has been misunderstood as extremely patronizing and degrading for women in his talk at Oxford University entitled "Islam in the $21^{\text {st }}$ century" when he was asked by one of his audience, the secretary head of Oxford Union. He emphasized that to wear hijab is to protect and uplift the status of women as it is a symbol of modesty as can be seen in the following extract of his talk;

"...if women wear revealing clothes, there are more chances of being raped ... on March 9, 2009 in Britain, one out of seven British people believe that women who wear revealing and sexy clothes should be hit, I disagree with this... one article in 2005 , in the same paper, the Sunday Times, it said that $26 \%$ of the British people who wear revealing clothes is partially or totally responsible for the rape. So what I say, the more modest you dress up, the more you are respected. So, Islam has prescribed the modest hijab for the woman, not to degrade her but to uplift her. I do agree maybe there are cultural differences. Islam cannot force anyone to adopt it. There are cultural differences for example, in some societies, even looking at the woman is immodest. Some societies feel that looking is no problem, but touching women is immodest. Some societies feel that shaking hand is no problem, some societies feel kissing is no problem. Some societies feel that doing anything as long as both parties agree, no problem. Different societies have different cultures, different rules and regulations. When I went to America, while I was giving a talk, one of the Americans said, "you Eastern woman, you immodest!" I was shocked. I said, "why do you call the Eastern woman immodest?" He told me Eastern women exposed their belly. So, exposing your belly is immodesty. In India, exposing belly is not immodest, wearing shorts is immodesty. So what you have to realize sister, there are different cultures, there are different systems. Islam cannot force anyone to adopt. It's clearly mentioned in surah Al-Baqarah, chapter 2 verse 256; there is no compulsion in religion", but if some women want to adopt the hijab because they feel modest and they feel respected, I feel no other woman should disagree. When I went to U.K., I've seen hundreds and thousands of women who cover their hair and they feel uplifted because of its modesty. Hope that answer the question".

Another function of the usage of Islamic English in Zakir Naik's speeches is due to lack of equivalent word in the English language. In his speech entitled "The Solution for Humanity 2015" for instance, Islamic term solah has been introduced as an alternative to the word pray in the English language.

According to the Cambridge Advanced Learner's Dictionary [13], pray is "to speak to god either privately or in religious groups, to express gratitude, love and admiration or to ask for something" The Longman Dictionary of Contemporary English termed pray as "to wish or hope to God very strongly that their wish will come true" These definitions of pray do not capture the meaning as understood in Islam [14].

In this speech, an audience asked Zakir Naik as to why Muslims have to offer their prayers five times a day, which possibly questions the practicality of performing solah five times a day when a person could be preoccupied with works and daily problems. Dr. Zakir Naik then answered his question as shown in the extract below:

"Why do Muslims pray 5 times and Christians pray less? The reason is, for Muslims, solah is the programming towards righteousness. Normally people, they say pray. It's not the right translation of solah. Pray means to ask for help. In Oxford Dictionary, pray means besiege. In solah, we don't merely ask for help. Besides asking for help, we are asking guidance from Allah s.w.t. In other religions, they only ask for help. In Islam, besides asking for help, we are asking guidance from Allah s.w.t. For example, if the Imam, after surah Fatihah, he recites a verse from the Quran, surah al-Maidah, chapter number 5 , verse number 90; " $\mathrm{O}$ you believe, all intoxicants and gambling, dedication of stones, divination of arrows, abstain from this endeavour and you may prosper". Here we are getting guidance from Allah swt, in our solah that we will not have intoxicants, avoid gambling, avoid fortune telling, avoid idol worshipping, abstain and we as Muslims shall prosper."

In short, Zakir Naik clarified that solah in Islam does not only mean to ask God for something, but also to ask for help, forgiveness and seek guidance from Allah s.w.t. For this reason, the word pray cannot be substituted with the term solat as solat implies more meanings. As discussed by Noor, wrong definitions, spelling and pronunciation of Islamic divine terms could lead to mistaken belief, confusion and misinterpretation [15]. Each Islamic concept has its own meanings and related to Islamic notions of faith. In fact, Zakir Naik proposes the term solat to mean programming oneself towards righteousness to ensure one will always be on the right track.

"I prefer the meaning of solah as programming towards righteousness. If we analyse it today, the amount of evil around us, you know, bad things happening, evil thing, obscenity, cheating, there are high chances that we must be programmed. Our God, Almighty Allah Subhanahu wa ta'ala knows that we have to be programmed 5 times a day, so that we will be on the safe and straight track. For He is our creator, He knows that."

Besides to correct misconception and to provide an alternative to the absence of equivalent English words, 
Zakir Naik also use Islamic English to praise the Creator, Allah Subhanahu wa ta'ala and to cite the Quranic verses as mentioned earlier like surah Fatihah, surah al-Baqarah and surah al-Maidah.

In conclusion, Zakir Naik employed Islamic English as an attempt to correct mistranslation of Arabic divine words such as jihad, hijab and solah. It could also be seen that he utilized Islamic English to maintain the Arabic terms in the English language due to the absence of equivalent English words. Besides, he also used Islamic English to praise the Creator and Quranic verses. These points have been raised by alFaruqi when he proposed the need for Islamic English to be used in the English language [7]. Similarly, Maher Zain also employed Islamic English in his songs for the purposes of praising Allah and Prophet Muhammad and the absence of equivalent English words. Unlike Maher Zain who also used Islamic English as a form of $d u^{\prime} a$ and to evoke special attachment to Islam, Zakir Naik mainly utilized it to correct misconceptions that people have regarding the Arabic words [16].

\section{Conclusion}

As the English language has become more prominently used by the people around the world, Arabic words on the other hand have suffered changes and loss of meaning through translation process from Arabic to the English language. In order to correct mistranslation and misconception of Arabic divine words, such as jihad, hijab and solah, Zakir Naik provided clarifications to his audience. The attempt to define Arabic words in the English language may not capture the meaning as intended in Islam. In short, Zakir Naik made use of Islamic English language in his speeches mainly to show the urgency to correct the mistranslation of Arabic words into English words.

This study was funded by a research grant from the International Islamic University Malaysia.

\section{References}

1. F. Sharifian, Language and intercultural Communication (New York/London: Routledge, Taylor and Francis Group, 2013)

2. A. Mahboob, English as an Islamic language: A case study of Pakistani English, 28(2), 175-189. (2009)

3. A. Mahboob, T. Elyas, World Englishes, 33(1), 128-142 (2014)

4. H. Ahn, World Englishes, 33(2), 195-222 (2014)

5. P.G.L. Chew, World Englishes, 32(3), 380-394 (2013)

6. J. Lambert, World Englishes, 33(1),112-127 (2014)
7. I.R. Al-Faruqi, Toward Islamic English. Herndon: International Institute of Islamic Thought, 7-45 (1986)

8. A.S. Abdussalam, Islam And Language, 8 (Kuala Lumpur: Al-Hilal Publishing, 1999)

9. Zakir Naik's "Islam and $21^{\text {st }}$ century". Retrieved March 24, 2015 https://www.youtube.com/watch?v=rdoCzv28IOw (2015)

10. Zakir Naik's “Ask Dr.Zakir Naik in Dubai International Peace Convention" .Retrieved March 24, 2015 https://www.youtube.com/watch? $\mathrm{v}=\mathrm{mzPtHsb3fiw}$ (2015)

11. Zakir Naik's “Islam's View on Jihad and Terrorism "Retrieved March 24, 2015. https://www.youtube.com/watch?v=c7Hr8bW5Py U (2015)

12. Collins English Dictionary/ Always Free online. Retrieved December 30,2016 https://www.collinsdictionary.com/dictionary/engl ish (2006)

13. Cambridge Advanced Learner's Dictionary, Cambridge: Cambridge University Press, 774 (2008)

14. Longman Dictionary of Contemporary English, 2003. Oxford: Pearson Education, 1283 (2003)

15. M. H. Noor, A linguistic analysis of definitions of Islamic terms in the Oxford Advanced Learner's Dictionary (2005), the Macmillan English Dictionary for Advanced Learner's (2007) and the Cambridge Advanced Learner's (2008). 1112 (Unpublished master's thesis. Gombak, International Islamic University Malaysia, 2011)

16. K. Othman, F. Abdul Malik, Islamic English in Maher Zain's songs: Is there a need?, $1^{\text {st }}$ World International Conference on Islamic Sciences, $5^{\text {th }}$ $7^{\text {th }}$ December 2016, Kuala Lumpur. (2016) 